\title{
KOORDINASI DALAM PENANGANAN GELANDANGAN PIKOTIK DI KOTA BANDUNG
}

\section{COORDINATION IN HANDLING PSYCHOTIC VAGRANT IN BANDUNG CITY}

\author{
Andini Hening Safitri; Ida Widianingsih; Mas Halimah \\ aheningsafitri@ymail.com; ida.widianingsih@unpad.ac.id; mas.halimah@unpad.ac.id \\ Program Studi Administrasi Publik \\ Fakultas Ilmu Sosial dan Ilmu Politik \\ Universitas Padjadjaran \\ Bandung, Indonesia
}

\begin{abstract}
ABSTRAK
Latar belakang penelitian ini berawal dari fenomena masih sering ditemuinya gelandangan yang menderita gangguan jiwa atau gelandangan psikotik yang terlantar dan berkeliaran di kota-kota besar termasuk Kota Bandung. Metode yang digunakan dalam penelitian ini adalah metode penelitian kualitatif dengan pendekatan deduktif dengan mengacu pada koordinasi efektif yang dikemukakan oleh State Service Commision (2008), yang didalamnya terdapat tiga dimensi utama dalam koordinasi, yaitu dimensi mandat, sistem dan perilaku. Dari penelitian ini dapat disimpulkan bahwa koordinasi dalam penanganan gelandangan psikotik di Kota Bandung masih belum berkaitan dengan dimensi mandat, sistem dan perilaku. Agar koordinasi dalam penanganan gelandangan psikotik di Kota Bandung dapat berjalan efektif, diperlukan peningkatan dalam beberapa aspek yang berkaitan dengan dimensi koordinasi, yaitu dalam hal komitmen pemimpin, tujuan yang terdefinisikan secara jelas dan disepakati bersama, kerangka kerja dan akuntabilitas, pengukuran kinerja, ketepatan dan kemampuan perwakilan dan kepemimpinan dalam tim, serta budaya dan nilai bersama.
\end{abstract}

Kata Kunci: gelandangan psikotik, koordinasi, mandat, sistem, perilaku

\section{ABSTRACT}

The background of this research came from the phenomenon are often seen the homeless people with mental illness or psychotic vagrant displaced and wandering in major cities including Bandung. The method used in this study is a qualitative research method with a deductive approach by reference to the effective coordination proposed by the State Services Commission (2008), in which there are three main dimensions in coordination, the dimensions of the mandate, systems and behaviors. From this research, it can be concluded that the coordination in handling psychotic vagrant in Bandung still not associated with the dimensions of the mandate, systems and behaviors. In order to coordinate the handling of psychotic vagrant in Bandung can be effective, it needs improvement in some aspects related to the dimensions of coordination, namely in terms of commitment to leadership, the goals are clearly defined and agreed together, frameworks and accountability, performance measurement, accuracy and the ability of representation and leadership in the team, as well as shared culture and values.

Keywords: psychotic vagrants, coordination, mandates, systems, behaviors 


\section{PENDAHULUAN}

Sudah menjadi keharusan bagi suatu negara untuk merespon berbagai macam permasalahan yang muncul dimana permasalahan setiap negara akan berbeda dan akan berbeda pula dalam merespon Permasalahan

tersebut

(Nugroho,2014:29). Salah satu respon yang ditunjukan adalah merespon masalah sosial yang dilakukan melalui berbagai pelayanan sosial (Suharto,2006:4), dengan memberikan pelayanan berupa penjaminan sosial, perumahan, kesehatan, pendidikan dan pelayanan sosial personal (Suharto,2006:9).

Salah satu fenomena yang menunjukan bahwa masih adanya masalah sosial saat ini diantaranya dapat dilihat dari banyaknya Orang Dengan Gangguan Jiwa (ODGJ) yang sering berkeliaran dan terlantar di jalanan khususnya di kota-kota besar di Indonesia (perpustakaan.bppksyogyakarta.com:200 9). Masih ditemuinya fenomena tersebut menuntut keseriusan pemerintah untuk memberikan respon dengan cara memberikan pelayanan kesehatan, penjaminan sosial dan juga memberikan fasilitasi perumahan bagi gelandangan psikotik, yang mana dalam hal ini gelandangan psikotik termasuk kedalam jenis Penyandang Masalah Kesejahteraan Sosial (PMKS) yang menderita gangguan jiwa. Pentingnya peran pemerintah untuk menangani gelandangan psikotik tertuang dalam Undang-Undang Dasar 1945 pada pasal $28 \mathrm{H}$ ayat 1 , disebutkan bahwa setiap orang berhak hidup sejahtera lahir dan batin, bertempat tinggal, dan mendapatkan lingkungan hidup yang baik dan sehat serta berhak memperoleh pelayanan kesehatan. Melihat hal tersebut maka jelaslah bahwa gelandangan psikotik berhak mendapatkan lingkungan yang baik dan mendukung, serta berhak mendapatkan pelayanan kesehatan.

Dalam menangani gelandangan psikotik, tidak hanya pemerintah pusat saja yang berperan, tetapi juga menjadi tanggung jawab pemerintah daerah. Seperti disebutkan dalam UndangUndang Nomor 18 Tahun 2014 Tentang Kesehatan Jiwa dimana disebutkan pada Pasal 80 bahwa Pemerintah dan Pemerintah Daerah bertanggung jawab melakukan penatalaksanaan terhadap Orang Dengan Gangguan Jiwa (ODGJ) yang terlantar, menggelandang, mengancam keselamatan dirinya dan/atau orang lain, dan/atau mengganggu ketertiban dan/atau keamanan umum.

Beberapa daerah di Indonesia memiliki angka gangguan jiwa dan angka gelandangan psikotik yang cukup tinggi, diantaranya adalah Kota Bandung. Dari data Riset Kesehatan Daerah Provinsi Jawa Barat tahun 2007 diketahui bahwa warga pengidap gangguan jiwa di Kota Bandung mencapai 600.000 orang. Angka tersebut lebih besar jika dibandingkan dengan jumlah penduduk Kota Cimahi pada tahun yang sama yaitu tahun 2007 yang bedasarkan data Badan Pusat Statistik Kota Cimahi berjumlah 536.743 jiwa.

Selain tingginya angka gangguan jiwa di Kota Bandung, pada tahun 2015 Kota Bandung menjadi salah satu daerah di Jawa Barat yang menyumbang pasien gangguan jiwa terbanyak ke Rumah Sakit Jiwa Provinsi Jawa Barat, dimana hingga bulan September 2015 tercatat bahwa Kota Bandung menyumbang 11.363 pasien di Rumah Sakit Jiwa Provinsi Jawa Barat dan diantara pasien tersebut terdapat pasien yang merupakan gelandangan psikotik.

Berdasarkan data pasien gelandangan psikotik di Instalasi Kesehatan Jiwa Masyarakat pada tahun 2014 tercatat jumlah pasien gelandangan psikotik yang dirujuk ke RSJ Provinsi Jawa Barat oleh Pemerintah Kota Bandung adalah sebanyak 21 orang, dan jumlah tersebut merupakan jumlah tertinggi diantara daerah lainnya di Jawa Barat.

Tingginya angka gelandangan psikotik di Kota Bandung menuntut Pemerintah Kota Bandung untuk lebih 
pro-aktif dalam menangani hal tersebut. Dalam penanganannya tidak dapat satu lembaga saja yang terlibat mengingat gelandangan psikotik ini merupakan kategori gelandangan dan mengidap gangguan jiwa, maka dari itu diperlukan keterlibatan lembaga lain yang berwenang untuk menangani gelandangan psikotik di Kota Bandung secara menyeluruh. Berdasarkan Peraturan Gubernur Jawa Barat Nomor 45 Tahun 2012 Tentang Petunjuk Pelaksanaan Peraturan Daerah Provinsi Jawa Barat Nomor 11 Tahun 2010 Tentang Penyelenggaraan Kesehatan pasal 33 yang menyebutkan bahwa:

"Dalam rangka penyaringan proses pasien psikotik gelandangan, Dinas melaksanakan koordinasi dengan Dinas Sosial,Dinas Kesehatan Kabupaten/Kota, Rumah Sakit Jiwa, Satuan Polisi Pamong Praja dan Kepolisian"

Selain lembaga-lembaga yang disebutkan oleh Peraturan Gubernur Jawa Barat Nomor 45 Tahun 2012 di atas, pihak lainnya yang juga terlibat dalam penaganan gelandangan psikotik adalah Komando Distrik Militer (Kodim) 0618/BS Kota Bandung.

Dalam penanganan gelandangan psikotik di Kota Bandung saat ini, penulis menemukan bahwa terdapat beberapa indikasi masalah dalam koordinasi penanganan gelandangan psikotik, diantaranya adalah belum adaya pedoman yang disepakati bersama yang digunakan oleh pihak yang terlibat, yang berkaitan dengan penanganan gelandangan psikotik di Kota Bandung. Belum adanya pedoman tersebut diantaranya menyebabkan belum adanya pola yang jelas terkait dengan penanganan gelandangan psikotik khususnya terkait dengan penanganan pasca rehabilitasi. Selain itu juga dalam membahas penanganan gelandangan psikotik di Kota Bandung tidak ada pertemuan khusus yang terjadwal rutin dan berkala yang bersifat formal, dan juga Informasi terkait gelandangan psikotik yang tidak merata dimana berdasarkan pengamatan awal dan wawancara awal yang penulis lakukan, penulis melihat bahwa tidak semua pihak yang terlibat dalam penanganan gelandangan psikotik di Kota Bandung mengetahui dan memiliki data pasti terkait jumlah gelandangan psikotik di Kota Bandung dan mengetahui apakah gelandangan psikotik yang dijangkau benar-benar mendapatkan perawatan yang sesuai hingga mendapatkan rehabilitasi sosial atau tidak. Berdasarkan indikasi yang penulis temukan, maka penulis ingin mengetahui bagaimana koordinasi dalam penanganan gelandangan psikotik di Kota Bandung.

\section{METODE}

Pada penelitian ini, penulis menggunakan metode penelitian kualitatif dengan pendekatan deduktif. Pemilihan metode tersebut dikarenakan dalam penelitian ini penulis bertujuan untuk mencari tahu secara mendalam terkait koordinasi dalam penanganan gelandangan psikotik di Kota Bandung. Kemudian pendekatan deduktif dipilih oleh penulis mengingat dalam penelitian ini penulis mengacu pada teori yang relevan yaitu mengenai dimensi dalam koordinasi. Dengan pendekatan ini penulis dapat memulai melakukan penelitian dengan teori acuan yang relevan (Yin, 2011:95) untuk menggali informasi lebih jauh terkait dengan koordinasi dalam penanganan gelandangan psikotik di Kota Bandung.

\section{HASIL DAN PEMBAHASAN}

Berdasarkan teori yang menjadi acuan dalam penelitian yang penulis lakukan, koordinasi dalam penanganan gelandangan psikotik di Kota Bandung dilihat dari tiga dimensi diamana setiap dimensi memiliki aspek-aspeknya sendiri yang diuraikan sebagai berikut:
A. Dimensi Mandat
Pada dimensi ini terdapat tiga aspek yang berkaitan dengan koordinasi, yaitu 
komitmen pemimpin, keterlibatan stakeholder dan tujuan yang didefiniskan secara jelas dan disepakati bersama.

a. Komitmen Pemimpin

Dalam koordinasi penanganan gelandangan psikotik, komitmen dari pemimpin lembaga-lembaga yang terlibat menjadi sangatlah penting, dimana juga disebutkan oleh State Services Commission (2008:12) bahwa "...the senior leaders have invested significant time and energy modelling and supporting this way of working. Komitmen dalam penanganan gelandangan psikotik ini diantaranya dapat terlihat dari diprioritaskannya penanganan gelandangan psikotik oleh lembaga-lembaga yang terlibat dalam penanganan gelandangan psikotik di Kota Bandung, dituangkannya komitmen kedalam bentuk yang formal seperti surat keputusan ataupun juga peraturan bersama, selain itu juga dapat terlihat dari disediakannya sarana prasarana.

Dari penelitian yang penulis lakukan dapat dilihat bahwa komitmen yang terbentuk masih belum optimal. Dimana saat ini tidak ada program khusus yang berkaitan dengan gelandangan psikotik dan sejauh ini prioritas dalam hal penanganan gelandangan psikotik adalah ketika ditemukan kasus tersebut maka semua lembaga yang terkait dalam penanganan gelandangan psikotik ikut turun tangan dan menindaklanjuti gelandangan psikotik. Selain itu saat ini belum ada satu bentuk komitmen dalam penanganan gelandangan psikotik yang sifatnya formal yang mengatur secara kseluruhan terkait penanganan gelandangan psikotik di Kota Bandung.

Dalam hal sarana prasarana yang disediakan untuk mendukung pelaksanaan penanganan gelandangan psikotik juga masih terdapat kekurangan dimana Pemerintah Kota Bandung tidak memiliki panti rehabilitasi eks-psikotik bagi yang tidak memiliki keluarga. Walaupun demikian, saat ini Dinas Sosial selaku pihak yang bertanggungjawab dalam hal rehabilitasi sosial sudah berupaya semaksimal mungkin dengan membangun kerja sama dengan panti rehabilitasi swasta ataupun panti rehablitasi yang berasal dari swadaya masyarakat.

\section{b. Keterlibatan Stakeholder \\ Keterlibatan menjadi kunci utama dari keberlangsungan aktivitas} koordinasi. Ketika pihak-pihak yang terlibat dalam penanganan gelandangan psikotik tidak terlibat, maka penanganan gelandangan psikotik tidak akan berjalan baik. Pada koordinasi penanganan gelandangan psikotik di Kota Bandung ini melibatkan berbagai macam lembaga dimana jika mengacu pada Peraturan Gubernur Provinsi Jawa Barat Nomor 45 Tahun 2012, disebutkan bahwa lembagalembaga yang terlibat dalam penanganan gelandangan psikotik diantaranya adalah Dinas Kesehatan, Dinas Sosial, Satpol PP, Kepolisian dan RSJ. Diluar itu, Pemerintah

Kota Bandung ikut melibatkan Kodim 0618/BS dalam penanganan gelandangan psikotik.

Pada aspek keterlibatan stakeholder dalam penanganan gelandangan psikotik, berdasarkan penelitian yang sudah dilakukan saat ini sudah baik. Dimana semua lembaga yang terlibat dalam penanganan gelandangan psikotik sudah berpartisipasi aktif sesuai dengan kapasitasnya masing-masing. Selain itu dalam hal keterlibatan dari masyarakat untuk ikut melaporkan keberadaan gelandangan psikotik juga sudah cukup baik, dimana melalui media pengaduan yang disediakan oleh Pemerintah Kota Bandung yaitu twitter, cukup banyak laporan dari masyarakat terkait dengan keberadaan gelandangan psikotik di Kota Bandung.
c. Tujuan yang Jelas dan Disepakati Bersama


Pada dimensi mandat, adanya tujuan yang jelas dan di sepakati bersama merupakan hal yang penting dalam melaksanakan koordinasi penanganan gelandangan psikotik. Mengingat banyaknya lembaga yang terlibat dalam penanganan gelandangan psikotik maka tujuan yang ditetapkan juga haruslah dapat difenisikan dengan jelas dan disepakati bersama agar hasil yang diinginkan dapat tercapai. Disebutkan juga oleh State Services Commission (2008:13) bahwa "......If objectives are unclear or not shared, participants may work towards different, incompatible goals and fail to achieve desired outcomes."

Penulis melihat bahwa dalam hal tujuan penanganan gelandangan psikotik di Kota Bandung belum didefinisikan dengan baik dan jelas. Hal tersebut dikarenakan belum adanya pedoman bersama yang sifatnya formal yang sudah disepakati oleh masing-masing pihak yang berkoordinasi. Walaupun di satu sisi koordinasi dalam penanganan gelandangan psikotik sudah berjalan dan semua pihak sudah menyepakati untuk melakukan penanganan gelandangan psikotik sesuai dengan tugas pokok dan fungsi serta kapasitas dan kewenangannya, disisi lain penulis melihat pentingnya membuat pedoman formal yang menguraikan tujuan dan sasaran yang jelas, dimana pedoman tersebut merupakan pedoman yang sudah disepakati bersama. Hal tersebut penulis anggap penting agar nantinya tidak terjadi saling lempar tugas dalam penanganan gelandangan psikotik di Kota Bandung.

\section{B. Sistem}

Dimensi sistem dalam koordinasi berkaitan dengan kerangka kerja dan akuntabilitas. Hal lain yang berkaitan dengan dimensi ini adalah adanya ketepatan dan kecukupan sumber daya yang dibutuhkan, proses mengawasi dan menilai bagaimana kinerja dari koordinasi dalam penanganan gelandangan psikotik. a. Kerangka Kerja dan Akuntabilitas

Adanya kerangka kerja yang jelas yang menjabarkan tugas dan fungsi dari masing-masing pihak, akan mencegah dari adanya tumpang tindih tugas, selain itu juga alur kerja akan menjadi lebih jelas. Dalam aspek kerangka kerja dan akuntabilitas, penulis melihat bahwa hal tersebut belum berjalan dengan baik, dikarenakan belum adanya bentuk pertanggungjawaban khusus yang berkaitan dengan penananganan gelandangan psikotik dan bentuk pelaporan tidak bersifat menyeluruh karena laporan yang dibuat terpisah pada masing-masing lembaga. Selain itu juga penulis melihat bahwa belum adanya kejelasan terkait pemulangan gelandangan psikotik dan eks-psikotik ke keluarganya, serta peran dalam pasca rehabilitasi sosial bagi eks-psikotik. Kemudian juga penulis masih melihat bahwa dalam upaya Perkesmas yang dilakukan oleh Dinas Sosial masih terdapat kendala terkait dengan keberadaan eks-psikotik di panti rehabilitasi.

\section{b. Kecukupan dan Ketersediaan}

Sumber Daya

Dalam berbagai macam kegiatan, ketersediaan sumber daya merupakan salah satu aspek pendukung yang akan berpengaruh pada keberlangsungan dan keberlanjutan suatu kegiatan. Begitupun juga dengan koordinasi dalam penanganan gelandangan pskotik yang membutuhkan sumber daya termasuk anggaran, dan ketersediaan waktu, agar penanganan yang diberikan dapat lebih menyeluruh dan berkelanjutan.

Dalam aspek ketersediaan dan kecukupan sumber daya penulis melihat bahwa penanganan gelandangan psikotik sudah difasilitasi dengan anggaran dan waktu yang cukup. Walaupun saat ini belum ada penganggaran secara khusus yang ditujukan untuk koordinasi penanganan gelandangan psikotik dengan 
lebih spesifik, namun kegiatan penanganan gelandangan psikotik dapat berjalan dengan bertumpu pada anggaran dari masing-masing lembaga yang terlibat.

\section{c. Pengukuran Kinerja}

Mengukur kinerja terhadap suatu kegiatan sangatlah penting, baik itu jangka panjang maupun jangka pendek. Dengan adanya pengukuran kinerja dapat diketahui sejauh mana keeberhasilan kegiatan itu dilakukan. Adanya mekanisme pengukuran dalam kegiatan yang dilakukan oleh pemerintah sangatlah penting, terlebih dalam penanganan gelandangan psikotik yang melibatkan banyak pihak. Penulis melihat bahwa dalam aspek pengukuran kinerja dalam penanganan gelandangan psikotik masih belum dipenuhi dengan baik, megingat tidak adanya sasaran dan indikator yang jelas untuk melihat sejauh mana keberhasilan Pemerintah Kota Bandung dalam menangani gelandangan psikotik.

\section{Perilaku}

Dimensi perilaku dalam koordinasi penanganan gelandangan psikotik ini berkaitan dengan ketepatan dan kemampuan dari perwakilan serta kepemimpinan tim. Dimensi ini juga berkaitan dengan perilaku dan budaya organisasi diantaranya dapat dilihat dari adanya dukungan setiap organisasi yang terlibat dalam penanganan gelandangan psikotik di Kota Bandung. Selain itu, dimensi ini berkaitan dengan adanya rasa kebersamaan antara pihak yang terlibat dalam koordinasi penanganan gelandangan psikotik di Kota Bandung.

\section{a. Ketepatan, Kemampuan dan \\ Kepemimpinan dalam Tim}

Dalam koordinasi penanganan gelandangan psikotik di Kota Bandung yang melibatkan banyak lembaga, melihat kemampuan dan ketepatan orang-orang yang ditunjuk masing-masing lembaga dalam berkoordinasi sangatlah penting.
Selain itu kepemimpinan yang baik dalam koordinasi penanganan gelandangan psikotik akan berdampak pada baik buruknya penanganan yang diberikan.

Pada aspek ini, penulis melihat bahwa dalam hal kemampuan dan ketepatan sudah cukup baik, dimana pihak yang terlibat melakukan kegiatan sesuai dengan kapasitas dan kemampuannya. Selain itu juga pihak-pihak terkait sudah mampu berkomunikasi dengan baik dan memanfaatkan teknologi, walaupun pertukaran informasi masih belum menyeluruh. Hanya saja dalam hal kepemimpinan tim belum dapat dirasakan, mengingat dalam penanganan gelandangan psikotik ini belum terbentuk tim khusus yaitu TP-KJM, dan hanya terdapat tim-tim kecil yang kadang berubah-ubah.

b. Budaya Organisasi yang Mendukung Koordinasi

Dalam koordinasi yang melibatkan banyak pihak, maka budaya organisasi dari masing-masing pihak tersebut menjadi suatu hal yang sangat penting. salah satu upaya untuk membangun hal tersebut diantaranya dengan adanya dukungan dengan mengintegrasikan kegiatan yang dilakukan dalam koordinasi ke dalam lembaga dari masing-masing pihak yang terlibat, seperti adanya program atau kegiatan pendukung dalam penanganan gelandangan psikotik di masing-masing lembaga yang terlibat (State Services Commission,2008:17).

Terkait dengan aspek budaya organisasi yang mendukung koordinasi dalam penanganan gelandangan psikotik penulis menilai bahwa aspek tersebut sudah cukup mendukung. Hal tersebut terlihat dari adanya kegiatan lain yang dilakukan oleh beberapa lembaga, sehingga bentuk dukungan tersebut akan mempermudah dalam pelaksanaan penanganan gelandangan psikotik di Kota Bandung.

c. Budaya dan Nilai Bersama 
Adanya budaya dan nilai bersama dari pihak yang berkoordinasi dalam penanganan gelandangan psikotik diantaranya ditandai dengan adanya kebersamaan yang terbangun dengan baik dan nilai yang dijunjung bersama oleh masing-masing pihak.. Selain itu, pemahaman yang baik dari masingmasing pihak yang terlibat terkait bagaimana tugas pokok dan fungsi dari lembaga lain. Dengan adanya nilai yang dianut bersama dan pemahaman yang baik antar masing-masing pihak diharapkan rasa kepemilikan akan terbentuk dan dapat mendukung koordinasi penanganan gelandangan psikotik di Kota Bandung.

Dari penelitan yang penulis lakukan, saat ini dalam penanganan gelandangan psikotik di Kota Bandung belum ada nilai yang dijunjung bersama. Namun demikian dalam hal pemahaman dan saling mengerti akan tugas pokok dan fungsi antar masing-masing lembaga sudah terdapat satu pemahaman yang cukup baik.

\section{SIMPULAN DAN SARAN Simpulan}

Berdasarkan hasil penelitian yang sudah diuraikan oleh penulis pada bab sebelumnya, dapat disimpulkan bahwa koordinasi dalam penanganan gelandangan psikotik belum sepenuhnya berkaitan dengan dimensi mandat, dimensi sistem dan dimensi perilaku, dimana hanya beberapa hal saja yang sudah cukup baik dan sudah dipenuhi dari ketiga dimensi tersebut, yaitu yang berkaitan dengan keterlibatan stakeholder, kecukupan dan ketersediaan sumber daya dan budaya organisasi yang mendukung koordinasi. Untuk hal lainnya seperti komitmen pemimpin, tujuan yang jelas dan disepakati bersama, kerangka kerja dan akuntabilitas, pengukuran kinerja, ketepatan dan kemampuan perwakilan juga kepemimpinan dalam tim serta pertukaran budaya dan nilai bersama yang masih belum terbentuk dengan baik.

\section{Saran}

Saran penulis untuk koordinasi

dalam penanganan gelandangan psikotik di Kota Bandung, yaitu:

1. Membentuk TP-KJM Kota Bandung. Dengan dibentuknya tim tersebut diharapkan penanganan terhadap gelandangan psikotik dapat lebih menyeluruh dan penanganan tidak hanya dilakukan hingga tahap rehabilitasi sosial saja, melainkan pada pasca rehabilitasi sosial.

2. Membuat pedoman penanganan gelandangan psikotik yang disepakati bersama. Dengan adanya pedoman tersebut diharapkan kerangka kerja dalam penanganan gelandangan psikotik akan lebih jelas dan meyeluruh. Selain itu dengan adanya pedoman yang disepakati bersama, hal-hal yang berkaitan dengan tujuan, sasaran dan indikator kegiatan dapat dijabarkan dengan jelas.

3. Membuat pendataan terkait gelandangan psikotik secara lebih merinci, terkait dengan jumlah gelandangan psikotik yang berhasil dijangkau, yang dikembalikan kembali kepada keluarga, gelandangan psikotik yang dirujuk, gelandangan psikotik yang direhabilitasi dan dimana yang bersangkutan tersebut direhabilitasi.

4. Melakukan rapat evaluasi yang jangka waktunya ditetapkan. Adanya rapat evaluasi ini bertujuan untuk melakukan penyebaran informasi terkait gelandangan psikotik di Kota Bandung dan mengevaluasi sudah sejauh mana penanganan gelandangan psikotik dilakukan serta apa saja kendala yang ditemui dalam penanganan gelandangan psikotik.

5. Melakukan follow-up pada saat pemulangan gelandangan psikotik ataupun juga eks-psikotik kepada pihak keluarga. Follow-up yang dilakukan dapat berupa kunjungan rumah dari pihak Pemerintah Kota 
Bandung disertai pihak dinas tempat asal yang bersangkutan.

\section{DAFTAR PUSTAKA}

\section{Buku}

Centre for Mental Health, Department of Health, Mind, NHS Confederation Mental Health Network, Rethink Mental Illness, Turning Point. 2012. No Health Without Mental Health: Implementation Framework. London.

Creswell, John W. 2014. Research Design Pendekatan Kualitatif, Kuantitatif, dan Mixed. Yogyakarta: Pustaka Pelajar.

Manullang, M. (2006). Dasar-Dasar Manajemen.Yogyakarta: Gadjah Mada

New Zealand Office of the Controller and Auditor General. 2003. Key Success Factors for Effective Coordination and Collaboration Between Public Sector Agencies. New Zealand: Report of the Controller and Auditor General

Nugroho, Riant. 2014. Public Policy. Jakarta: Elex Media Komputindo.

Ritchie, Jane., dan Jane Lewis. 2003. Qualitative Research Practice A Guide for Social Science Students and Researchers. London: Sage Publications.

State Services Commision. 2008. Factors for Successful Coordination - A Framework to Help State Agencies Coordinate Effectively. New Zealand: State Services Commission

Sugandi, Yogi S. 2011. Administrasi Publik Konsep dan Perkembangan Ilmu di Indonesia.Yogyakarta: Graha Ilmu.
Sung Min, Park., dan Kim Seona. 2014. Public Management A Case Handbook. Seoul: Sungkyunkwan University Press

Syafiie, Inu Kencana. 2010. Ilmu Administrasi Publik (Edisi Revisi). Jakarta: PT.Rineka Cipta

Syafri, Wirman. 2012. Studi tentang Administrasi Publik. Jakarta: Erlangga

Sugiyono.2013. Metode Penelitian Administrasi.Bandung: Alfabeta.

Yin, Robert K.. 2011. Qualitative Research from Start to Finish. United States Of America: The Guilford Press.

\section{Jurnal}

Boella, Guido., Leendert van der Torre.2005.Coordination and Organization Definitions, Examples and Future Research. Electronic Notes in Theoretical Computer Science Directions

Harpham, Trudy., Michael Reichenheim, Rebecca Oser, Elizabeth Thomas, Narmeen Hamid, Surinder Jaswal, Ana Ludermir dan Magna Aidoo. 2003. Measuring mental health in a cost-effective manner. Oxford University Press Health policy and planning;18(3):344-9.

Iskandar, Shelly., Dien Mardiningsih., Deni Kurniadi Sunjaya., Arifah Nur Istiqomah., \& Teddy Hidayat. 2013. Menuju Jawa Barat Bebas Pasung: Komitmen Bersama 5 Kabupaten Kota.

Král, Jaroslav. 2007. Introduction to Coordination Concept Suharto, Edi. 2006. Kebijakan Sosial. 
Tim Peneliti Balitbang Provinsi Jawa Tengah.2007. Study Penanganan Masalah Sosial Gelandangan Psikotik di Wilayah Perbatasan dan Perkotaan. Semarang:Balitbang Jawa Tengah

Vanagas, Ramunas., dan Janina Stakevic. 2014 Impact of Coordination for Organization Process. Intellectual Economics, Vol.8, No.2(20), p. 112125

Research Introduction.

- Qualitative

Washington, DC:

Center for Teaching, Research \& Learning.

\section{Skripsi}

Mediana, Viska. 2012. Analisis Koordinasi Dinas Perhubungan dalam Penyediaan Pelayanan Jasa Transportasi Angkutan Kota di Depok. Depok: Universitas Indonesia

\section{Dokumen}

Undang - Undang Dasar Negara Republik Indonesia Tahun 1945

Undang-Undang Republik Indonesia Nomor 3 Tahun 1966 Tentang Kesehatan Jiwa

Undang-Undang Republik Indonesia Nomor 36 Tahun 2009 Tentang Kesehatan

Undang-Undang Republik Indonesia Nomor 18 Tahun 2014 Tentang Kesehatan Jiwa

Undang-Undang Republik Indonesia Nomor 2 Tahun 2002 Tentang Kepolisian Negara Republik Indonesia
Peraturan Menteri Sosial Republik Indonesia Nomor 08 Tahun 2012 Tentang

Pedoman Pendataan Dan Pengelolaan Data Penyandang Masalah Kesejahteraan Sosial Dan Potensi Dan Sumber Kesejahteraan Sosial

Keputusan Menteri Kesehatan Republik Indonesia Nomor: 220/MENKES/SK/III/2002 Tentang Pedoman Umum Tim Pembina, Tim Pengarah, Tim Pelaksana Kesehatan Jiwa Masyarakat ( TP - KJM )

Peraturan Gubernur Jawa Barat Nomor 45 Tahun 2012 Tentang Petunjuk Pelaksanaan Peraturan Daerah Provinsi Jawa Barat Nomor 11 Tahun 2010 Tentang Penyelenggaraan Kesehatan

Keputusan Gubernur Jawa Barat Nomor 440.05/Kep.372/Yansos/2014 Tentang Tim Penanggulangan Kesehatan Jiwa Masyarakat Provinsi Jawa Barat

Peraturan Daerah Kota Bandung Nomor 11 Tahun 2005 Tentang Perubahan Atas Peraturan Daerah Kota Bandung Nomor 03 Tahun 2005 Tentang Penyelenggaraan Ketertiban, Kebersihan Dan Keindahan

Peraturan Daerah Kota Bandung Nomor 13 Tahun 2007 Tentang Pembentukan Dan Susunan Organisasi Dinas Daerah Kota Bandung

Peraturan Daerah Kota Bandung Nomor 10 Tahun 2009 Tentang Sistem Kesehatan Kota Bandung.

Peraturan Daerah Kota Bandung Nomor 06 Tahun 2013 Tentang Pembentukan Dan Susunan 
Organisasi Satuan Polisi Pamong Praja

Anggaran Pendapatan Belanja Daerah Kota Bandung Tahun 2016

Laporan Hasil Riset Kesehatan Dasar (Riskesdas) Provinsi Jawa Barat Tahun 2007

Lampiran III Peraturan Daerah Provinsi Jawa Barat Nomor 10 Tahun 2015 Laporan Pejabat Pelaksana Teknis Kegiatan Sarana dan Prasarana Panti

Persinggahan Rumah Singgah Kota Bandung Periode Juli s/d Desember 2014

Laporan Pasien Gelandangan Psikotik Instalasi Kesehatan Jiwa Masyarakat dan Promosi Kesehatan Rumah Sakit (PKRS) Periode Januari s/d Agustus 2015

Riset Kesehatan Dasar Badan Penelitian dan Pengebangan Kesehatan Kementerian Kesehatan Republik Indonesia Tahun 2010

Riset Kesehatan Dasar Badan Penelitian dan Pengebangan Kesehatan Kementerian Kesehatan Republik Indonesia Tahun 2013

Strategi Nasional Sistem Kesehatan Jiwa Direktur Jenderal Bina Upaya Kesehatan Kementerian Kesehatan Republik Indonesia Tahun 2015

\section{Internet}

http://www.kompasiana.com/naftalia/aw as-ada-orang-gila-edisi-harikesehatan-jiwasedunia_561bdef06c7a61f90b8b456 $b$ (Diakses 28 November 2015 pukul $12: 48)$

http://www.unpad.ac.id/profil/drsuryani-skp-mhsc-setiap-tahun- penderita-gangguan-jiwa-diindonesia-terus-meningkat/ (Diakses 28 November 2015 pukul 13:39)

http://psikotikz.blogspot.co.id/2013/12/re habilitasi-sosial-gelandangan psikotik.html (Diakses 10 Februari 2016 pukul 14:20)

http://bandungekspres.co.id/2015/penyan dang-psikotik-alami-penurunan/

(Diakses 13 April 2016 pukul 13:15)

http://bandung.merdeka.com/halobandung/dinsos-imbau-masyarakattak-beri-uang-anak-punk-dangepeng-di-jalanan-160106z. html (Diakses 15 April 2016 pukul 10:12)

http://portal.bandung.go.id/wakil-walikota-bandung-berikan-bantuansosial (Diakses pada 20 Mei 2016 pukul 18:40)

http://bandungekspres.co.id/2015/sebarorang-gila-di-bandung-barat/2/

(Diakses 24 Mei 2016 pukul 15:54)

http://www.republika.co.id/berita/nasion al/daerah/16/03/15/o433zw280-15titik-penyebaran-pmks-kotabandung-terus-dipantau (Diakses 31 Mei 2016 pukul 18:07)

http://www.pikiranrakyat.com/ekonomi/2015/11/21/350 770/inilah-umk-jabar-2016-yangditetapkan-gubernur (Diakses 9 Juni 2016 pukul 21:17)

http://dinsos.bandung.go.id/BeritaFront/ Detail/38 (Diakses pada 15 Juni 2016 pukul 14:29)

http://perpustakaan.bbppksyogyakarta.co $m /$ index.php? $p=$ show_detail\&id $=20$ 44 (Diakses pada 15 Juni pukul 14:57) 
http://rsj.jabarprov.go.id/?viewPage $=$ Ra watJiwaIntensif\& $m k=3 \& i m=25 \& l a$ $n g=i d$ (Diakses pada 15 Juni 2016 pukul 17:15)

http://rsj.jabarprov.go.id/?viewPage $=$ ten ang\& $m k=3 \& i m=26 \&$ lang $=i d$

(Diakses pada 15 Juni pukul 17:17)

https://twitter.com/Dinsos_BDG/media

(Diakses pada 22 Mei 2016 pukul 18:07)

https://twitter.com/search? src $=$ typd $\& q=$ psikotik\%20bandung (Diakses pada 22 Mei 2016 pukul 18:15)

https://twitter.com/FKTKSKBANDUNG/s tatus/676984148872032256

(Diakses pada 22 Mei 2016 pukul 18:27) 